\title{
$\nabla$
}

\section{Angiosarcoma in HIV-negative patients is not associated with HHV-8*}

\author{
João Avancini ${ }^{1}$ \\ Andre Pires Zanata Cherubim ${ }^{1}$ \\ Cristina Mendes de Oliveira ${ }^{1}$ \\ Neusa Yuriko Sakai Valente ${ }^{1}$ \\ Cyro Festa Neto ${ }^{1}$
}

\author{
José Antonio Sanches ${ }^{1}$ \\ Renato Pazzini ${ }^{1}$ \\ Laura Masami Sumita ${ }^{1}$ \\ Claudio Sergio Pannuti ${ }^{1}$
}

DOI: http:/ /dx.doi.org/10.1590/abd1806-4841.20164730

\begin{abstract}
BACKGROUND: Angiosarcoma is an aggressive, malignant neoplasm of vascular or lymphatic origin. Herpes virus 8 (HHV-8) is a member of the herpes family with a tropism for endothelial cells and it has been proven to induce vascular neoplasms, such as Kaposi's sarcoma. The role of HHV-8 in the pathogenesis of angiosarcoma has not been well defined.

Овлестіле: To investigate the relationship between the presence of HHV-8 and angiosarcoma.

MetHods: In this study, the team investigated the relationship between the presence of HHV-8, as determined by polymerase chain reaction, and angiosarcoma, using samples from patients with epidemic Kaposi's sarcoma as controls.

RESULTS: While all control cases with epidemic Kaposi's sarcoma were positive for HHV-8, none of the angiosarcoma cases was. CONCLUSION: These findings support most previous studies that found no association between HHV-8 and angiosarcoma.
\end{abstract}

Keywords: Hemangiosarcoma; Herpesvirus 8, human; HIV

\section{INTRODUCTION}

Angiosarcoma (AS) is an aggressive, malignant neoplasm of vascular or lymphatic origin. It is classified as a soft tissue sarcoma and accounts for $5.4 \%$ of all cutaneous sarcomas. ${ }^{1}$ AS is more common in the elderly, has no gender bias, and mainly affects Caucasians, with only $4 \%$ of cases involving black patients. ${ }^{1-3}$

Typically, AS affects the head and neck, and most commonly the scalp. ${ }^{1}$ Despite originating from endothelial cells, it rarely affects the great vessels or the heart. Most AS lesions have a spontaneous origin, although a number of risk factors have been identified, including chronic lymphedema, radiation therapy, genetic syndromes and occupational exposure to chemicals like vinyl chloride. ${ }^{1,4,5}$ A notable increase in the number of AS cases over the last thirty years has emerged, which may be related to both an increased use of radiotherapy and improved diagnostic methods. ${ }^{4,5}$ The contribution of immunosuppression to this is uncertain, with only a few reported cases of AS in transplant or AIDS patients. ${ }^{5}$

Herpes virus 8 (HHV-8), a member of the Herpesviridae family with a tropism for endothelial cells, is associated with vascular neoplasms in immunosuppressed patients, including those with epidemic Kaposi's sarcoma (EKS) or Castleman's disease, as well as the elderly (classic Kaposi's sarcoma). The role of HHV-8 in the etiology of AS remains unclear. ${ }^{1,6,7}$ Thus, in this study, the team evaluated the association between HHV-8 and AS in Brazilian patients.
The aim of this study was to identify HHV-8 DNA in tumor samples from patients with AS and HIV-infected patients with EKS from a tertiary hospital in the city of São Paulo, Brazil.

\section{METHODS}

The team retrospectively analyzed data from patients with AS or EKS whose diagnoses were based on clinical suspicion and confirmed through histopathological examination between 1992 and 2013. A total of 15 tissue samples from AS patients were selected. All AS patients were HIV-negative. Samples from 12 EKS patients were selected to match the AS samples in the same period. Histopathological samples from all patients were reviewed by an experienced dermatopathologist.

\section{DNA extraction}

Four slices, each $10 \mu \mathrm{m}$-thick, were cut from a formalin-fixed, paraffin-embedded tissue block and used for DNA extraction with the NucleoSpin Tissue Kit (Macherey-Nagel, Germany), following the manufacturer's instructions.

\section{Human $\beta$-globin polymerase chain reaction}

To assess DNA quality and integrity, all samples were analyzed by polymerase chain reaction (PCR), using the $\mathrm{PCO} 3+$ / PCO4+ primers, to detect the presence of a 110 base pair (bp)

Received on 18.05.2015.

Approved by the Advisory Board and accepted for publication on 11.01.2016.

* Work performed at the Universidade de São Paulo (USP) - São Paulo (SP), Brazil.

Financial Support: None.

Conflict of Interest: None.

Universidade de São Paulo (USP) - São Paulo (SP), Brazil.

C2016 by Anais Brasileiros de Dermatologia 
fragment of the human $\beta$-globin gene. ${ }^{8}$

\section{HHV-8 detection}

Samples that were positive for human $\beta$-globin by PCR were further analyzed for the presence of four different HHV-8 genome regions. These consisted of two different fragments of the ORF-K1 variable-loop region, VR1 (380bp) and VR2 (336bp), and a 407bp fragment of the ORF-K12 region, using modified cycling conditions (initial denaturation of DNA at $95^{\circ} \mathrm{C}$ for 5 minutes; 40 cycles of $94^{\circ} \mathrm{C}$ for 50 seconds, $62^{\circ} \mathrm{C}$ for 50 seconds; and $72^{\circ} \mathrm{C}$ for 1 minute, followed by a final extension at $72^{\circ} \mathrm{C}$ for 10 minutes). ${ }^{8-10}$ The fourth real-time PCR assay was designed to detect a fragment from the ORF-73 region. ${ }^{11}$

\section{RESULTS}

Age, gender, ethnicity, and affected sites of the AS patients are summarized in table 1.

One of the 12 EKS samples and one of the 15 AS samples were excluded because no $\beta$-globin DNA could be detected (patients 14 and 25), indicating the absence of intact human DNA. Of the 11 samples from EKS patients tested for the presence of HHV-8 DNA, 10 entailed positive results. The patient sample that tested negative for HHV-8 DNA also had a very low level of $\beta$-globin DNA, which may explain why no viral DNA could be detected. The remaining 10 patients were used as positive controls.

In contrast to the samples from EKS patients, the $14 \mathrm{AS}$ patient samples were all negative for HHV-8. These findings are summarized in table 2 .

\section{DISCUSSION}

The patient cohort in this study broadly matched the previously described epidemiological profile of this disease, with an approximately equal distribution between men and women ( 9 women and 6 men), a relatively advanced mean age (72 years) and a predominance of Caucasian patients (87\% of the cohort was self-classified as belonging to this ethnic group) ${ }^{1-3}$ Likewise, with respect

TABLE 1: Angiossarcoma patients: age, gender, ethnicity, and affected sites

\begin{tabular}{cclll}
\hline Patient & Age (years) & Gender & Ethnicity & Affected site \\
1 & 85 & female & Caucasian & scalp \\
2 & 72 & male & Asian & head \\
3 & 68 & female & Caucasian & head \\
4 & 69 & female & Caucasian & arm \\
5 & 72 & male & Caucasian & head \\
6 & 67 & male & Caucasian & head \\
7 & 81 & male & Caucasian & head \\
8 & 79 & female & Caucasian & leg \\
9 & 66 & male & Caucasian & scalp \\
10 & 70 & female & Caucasian & head \\
11 & 70 & female & Caucasian & leg \\
12 & 59 & female & Caucasian & scalp \\
13 & 80 & female & Caucasian & arm \\
14 & 75 & male & Black & head \\
15 & 70 & male & Caucasian & head \\
\hline
\end{tabular}

to tumor location, the majority of patients in this study (75\%) had a primary AS in the head and neck region. The reason for this predilection is uncertain, but it is believed that ultraviolet rays may play a role. ${ }^{12}$ Four patients presented with AS lesions on the limbs, and the team identified chronic lymphedema in patients 8 and 11, a risk factor described for AS (Figure 1$){ }^{1}$

A number of studies have investigated whether HHV8 plays a role in the pathogenesis of AS, on the basis that this virus has a tropism for endothelial cells. HHV-8 was first isolated from patients with Kaposi's sarcoma (KS) and AIDS in $1994 .{ }^{13}$ It has oncogenic properties, but unlike other oncogenic viruses, it has a complex DNA-based genome, and infection not only leads to cell (endothelial) morphological changes, an increased growth rate, and extended life span, but it also causes the deregulation of angiogenesis, inflammation, and modulation of the immune system in favor of tumor growth. ${ }^{14}$

$\mathrm{KS}$ is a neoplasm with vascular proliferation that can present conventionally in immunosupressed patients or in patients who have previously undergone cancer treatment. It is endemic in some regions, but it can also occur epidemically due to HIV infection in immunosuppressed individuals. In all variants of KS, HHV-8 is implicated as the agent- inducing disease. The team therefore looked for a possible relationship between HHV-8 and other vascular neoplasms (such as AS), using EKS patient samples as positive controls for HHV-8 involvement. ${ }^{13}$

Soon after a relationship was discovered between HHV-8 and KS, McDonagh et al. ${ }^{7}$ published the first report on an association between AS and HHV-8 in 1996. Of the 24 cases selected from AS patients, 7 were positive for the presence of HHV-8 (29\%), as were all the KS controls. ${ }^{7}$ This involved a series of cases, but subsequent positivity of HHV-8 in AS samples have only been reported in isolated cases, and there have been no further studies to corroborate this finding." ${ }^{15-20}$ Indeed, other studies have failed to find this association between HHV-8 and AS. ${ }^{21-28}$ A possible explanation for why only McDonagh $e t$ al. have found this association may be the higher prevalence of HHV8 in Italy and Turkey, where the study was conducted. ${ }^{29}$

In 2005, Schmid and Zietz performed a study with 40 AS patients and also failed to find an association between HHV-8 and AS, although all the KS cases in this study were positive for the virus. ${ }^{6}$ Table 3 summarizes the previously published studies regarding the relationship between HHV8 and AS. ${ }^{30}$

In our study, none of the $14 \mathrm{AS}$ cases was positive for HHV8, in contrast to the EKS control cases, which were all positive for HHV-8. This is consistent with the findings of numerous other studies from different countries, which could not establish an association between HHV-8 and AS. Amongst the studies that did not identify HHV-8-positive AS, HIV serology was not addressed in 4 articles, which could make it more difficult to distinguish between AS and EKS. 7,15,17,18

The rate of HHV-8 infection varies worldwide, and the absence of HHV- 8 in the AS lesions of the Brazilian patients described here reflects the findings of other studies in countries where the virus has a low prevalence. 
TABLE 2: HHV-8 analysis in patients presenting AS and EKS

\begin{tabular}{|c|c|c|c|c|c|c|c|c|}
\hline Patient & Diagnosis & Histological review & $\beta$-globin & VR1 & VR2 & ORF-73 & K12 & HHV-8 result \\
\hline 1 & AS & Confirmed & positive & - & - & - & - & negative \\
\hline 2 & AS & Confirmed & positive & - & - & - & - & negative \\
\hline 3 & AS & Confirmed & positive & - & - & - & - & negative \\
\hline 4 & AS & Confirmed & positive & - & - & - & - & negative \\
\hline 5 & AS & Confirmed & positive & - & - & - & - & negative \\
\hline 6 & AS & Confirmed & positive & - & - & - & - & negative \\
\hline 7 & AS & Confirmed & positive & - & - & - & - & negative \\
\hline 8 & AS & Confirmed & positive & - & - & - & - & negative \\
\hline 9 & AS & Confirmed & positive & - & - & - & - & negative \\
\hline 10 & AS & Confirmed & positive & - & - & - & - & negative \\
\hline 11 & AS & Confirmed & positive & - & - & - & - & negative \\
\hline 12 & AS & Confirmed & positive & - & - & - & - & negative \\
\hline 13 & AS & Confirmed & positive & - & - & - & - & negative \\
\hline 14 & AS & Confirmed & negative & - & - & - & - & excluded \\
\hline 15 & AS & Confirmed & positive & - & - & - & - & negative \\
\hline 16 & EKS & Confirmed & positive & - & - & + & - & positive \\
\hline 17 & EKS & Confirmed & positive & - & - & + & - & positive \\
\hline 18 & EKS & Confirmed & positive & - & - & + & - & positive \\
\hline 19 & EKS & Confirmed & positive & - & - & + & - & positive \\
\hline 20 & EKS & Confirmed & positive & - & - & - & + & positive \\
\hline 21 & EKS & Confirmed & positive & + & + & + & - & positive \\
\hline 22 & EKS & Confirmed & positive & - & - & + & + & positive \\
\hline 23 & EKS & Confirmed & positive & - & - & + & + & positive \\
\hline 24 & EKS & Confirmed & positive & + & + & + & - & positive \\
\hline 25 & EKS & Confirmed & negative & - & - & - & - & excluded \\
\hline 26 & EKS & Confirmed & positive & - & - & + & - & positive \\
\hline 27 & EKS & Confirmed & low & - & - & - & - & negative \\
\hline
\end{tabular}

AS, angiosarcoma; EKS, epidemic Kaposi's sarcoma; HHV-8, herpes virus 8

TABLE 3: Previously published studies regarding the relationship

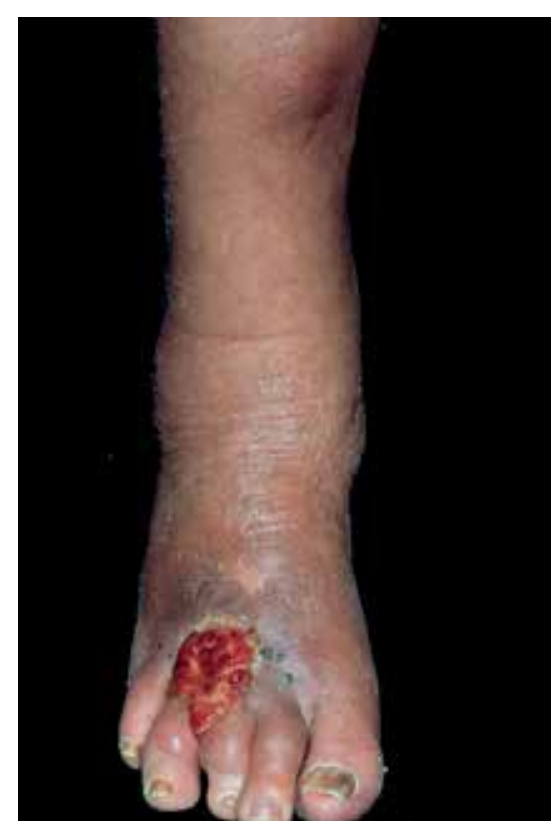

Figure 1:

Angiosarcoma lesion in a patient with chronic lymphedema

\section{CONCLUSION}

The Brazilian case series discussed in this report confirms the absence of HHV-8 in the AS lesions and adds data from a population between HHV-8 and AS

\begin{tabular}{|c|c|c|}
\hline Authors & $\begin{array}{l}\text { Number } \\
\text { of cases }\end{array}$ & $\begin{array}{l}\text { Positivity for HHV-8 } \\
\text { in AS } \% \text { (n) }\end{array}$ \\
\hline Mc Donagh et al. ${ }^{7}, 1996$ & 24 & $29(7 / 24)$ \\
\hline Tomita et al. $.^{21}, 1996$ & 35 & none \\
\hline Dictor et al. ${ }^{22}, 1996$ & 10 & none \\
\hline Jin et al. ${ }^{23}, 1996$ & 15 & none \\
\hline Koizumi et al. ${ }^{15}, 1996$ & 2 & $50(1 / 2)$ \\
\hline Gyulai et al. ${ }^{16}, 1996$ & 1 & $100(1 / 1)$ \\
\hline Gyulai et al. ${ }^{17}, 1997$ & 1 & $100(1 / 1)$ \\
\hline Takata et al. ${ }^{24}, 1997$ & 10 & none \\
\hline Viviano et al. $.^{25}, 1997$ & 17 & none \\
\hline Lasota et al. ${ }^{26}, 1999$ & 33 & none \\
\hline Palacios et al. ${ }^{27}, 1999$ & 11 & none \\
\hline Karpati et al. ${ }^{18}, 2000$ & 1 & $100(1 / 1)$ \\
\hline Remick et al. ${ }^{19}, 2000$ & 1 & $100(1 / 1)$ \\
\hline Fink-Puches et al. ${ }^{28}, 2002$ & 19 & none \\
\hline Gessi et al. $.^{20}, 2002$ & 1 & $100(1 / 1)$ \\
\hline Kamiyama et al. $.^{30}, 2004$ & 1 & none \\
\hline Schmid et al. ${ }^{6}, 2005$ & 40 & none \\
\hline TOTAL & 222 & $0.06(13 / 222)$ \\
\hline
\end{tabular}

AS, angiosarcoma; HHV-8, herpes virus 8

not yet reported. Hence, despite the characteristic endothelial tropism of HHV-8 and its association with some vascular tumors, such as KS, it does not seem to be involved in the pathogenesis of AS.] 


\section{REFERENCES}

1. Young RJ, Brown NJ, Reed MW, Hughes D, Woll PJ. Angiosarcoma. Lancet Oncol. 2010;11:983-91.

2. Rouhani P, Fletcher CD, Devesa SS, Toro JR. Cutaneous soft tissue sarcoma incidence patterns in the U.S.: an analysis of 12,114 cases. Cancer. 2008;113:616-27.

3. Mark RJ, Poen JC, Tran LM, Fu YS, Juillard GF. Angiosarcoma. A report of 67 patients and a review of the literature. Cancer. 1996;77:2400-6.

4. Stewart FW, Treves N. Lymphangiosarcoma in postmastectomy lymphedema; a report of six cases in elephantiasis chirurgica. Cancer. 1948;1:64-81.

5. Virtanen A, Pukkala E, Auvinen A. Angiosarcoma after radiotherapy: a cohort study of 332,163 Finnish cancer patients. Br J Cancer. 2007;97:115-7.

6. Schmid H, Zietz C. Human herpesvirus 8 and angiosarcoma: analysis of 40 cases and review of the literature. Pathology. 2005;37:284-7.

7. McDonagh DP, Liu J, Gaffey MJ, Layfield LJ, Azumi N, Traweek ST. Detection of Kaposi's sarcoma-associated herpesvirus-like DNA sequence in angiosarcoma. Am J Pathol. 1996;149:1363-8.

8. Whitby D, Marshall VA, Bagni RK, Wang CD, Gamache CJ, Guzman JR, et al. Genotypic characterization of Kaposi's sarcoma-associated herpesvirus in asymptomatic infected subjects from isolated populations. J Gen Virol. 2004;85:155-63.

9. de Souza VA, Sumita LM, Nascimento MC, Oliveira J, Mascheretti M, Quiroga $M$, et al. Human herpesvirus-8 infection and oral shedding in Amerindian and non-Amerindian populations in the Brazilian Amazon region. J Infect Dis. 2007;196:844-52.

10. Nascimento MC, Wilder N, Pannuti CS, Weiss HA, Mayaud P. Molecular characterization of Kaposi's sarcoma associated herpesvirus (KSHV) from patients with AIDS-associated Kaposi's sarcoma in Sao Paulo, Brazil. J Clin Virol. 2005;33:52-9

11. Krishnan HH, Naranatt PP, Smith MS, Zeng L, Bloomer C, Chandran B. Concurrent expression of latent and a limited number of lytic genes with immune modulation and antiapoptotic function by Kaposi's sarcoma-associated herpesvirus early during infection of primary endothelial and fibroblast cells and subsequent decline of lytic gene expression. J Virol. 2004;78:3601-20.

12. Albores-Saavedra J, Schwartz AM, Henson DE, Kostun L, Hart A, AngelesAlbores D, et al. Cutaneous angiosarcoma. Analysis of 434 cases from the Surveillance, Epidemiology, and End Results Program, 1973-2007. Ann Diagn Pathol. 2011;15:93-7.

13. Chang Y, Cesarman E, Pessin MS, Lee F, Culpepper J, Knowles DM, et al. Identification of herpesvirus-like DNA sequences in AIDS-associated Kaposi's sarcoma. Science. 1994;266:1865-9.

14. Cai Q, Verma SC, Lu J, Robertson ES. Molecular biology of Kaposi's sarcomaassociated herpesvirus and related oncogenesis. Adv Virus Res. 2010;78:87-142.

15. Koizumi $H$, Ohkawara $A$, Itakura 0 , Kikuta $H$. Herpesvirus-like DNA sequences in classic Kaposi's sarcoma and angiosarcoma in Japan. $\mathrm{Br} \mathrm{J}$ Dermatol. 1996;135:1009-10.

16. Gyulai R, Kemény L, Kiss M, Adám E, Nagy F, Dobozy A. Herpesvirus-like DNA sequence in angiosarcoma in a patient without HIV infection. N Engl $\mathrm{J}$ Med. 1996;334:540-1

17. Gyulai R, Kemény L, Kiss M, Nagy S, Adám E, Nagy F, et al. Human herpesvirus 8 DNA sequences in angiosarcoma of the face. Br J Dermatol. 1997;137:467.

18. Kárpáti S, Désaknai S, Désaknai M, Bíró J, Nagy K, Horváth A. Human herpesvirus type 8-positive facial angiosarcoma developing at the site of botulinum toxin injection for blepharospasm. Br J Dermatol. 2000;143:660-2.

19. Remick SC, Patnaik M, Ziran NM, Liegmann KR, Dong J, Dowlati A, et al. Human herpesvirus-8-associated disseminated angiosarcoma in an HIV-seronegative woman: report of a case and limited case-control virologic study in vascular tumors. Am J Med. 2000;108:660-4.

20. Gessi M, Cattani P, Maggiano N, Scambia G, Lauriola L, Ranelletti F0, et al. Demonstration of human herpesvirus 8 in a case of primary vaginal epithelioid angiosarcoma by in situ hybridization, electron microscopy, and polymerase chain reaction. Diagn Mol Pathol. 2002;11:146-51.

21. Tomita Y, Naka N, Aozasa K, Cesarman E, Knowles DM. Absence of Kaposi'ssarcoma-associated herpesvirus-like DNA sequences (KSHV) in angiosarcomas developing in body-cavity and other sites. Int J Cancer. 1996;66:141-2.

22. Dictor M, Rambech E, Way D, Witte M, Bendsöe N. Human herpesvirus 8 (Kaposi's sarcoma-associated herpesvirus) DNA in Kaposi's sarcoma lesions, AIDS Kaposi's sarcoma cell lines, endothelial Kaposi's sarcoma simulators, and the skin of immunosuppressed patients. Am J Pathol. 1996;148:2009-16.
23. Jin YT, Tsai ST, Yan JJ, Hsiao JH, Lee YY, Su IJ. Detection of Kaposi's sarcomaassociated herpesvirus-like DNA sequence in vascular lesions. A reliable diagnostic marker for Kaposi's sarcoma. Am J Clin Pathol. 1996;105:360-3.

24. Takata M, Hatta N, Takehara K, Fujiwara H. Absence of human herpesvirus-8 DNA in angiosarcomas and other skin tumours in immunocompetent patients, and in graft-versus-host disease in the immunosuppressed recipients of bone marrow transplants. Br J Dermatol. 1997;137:156-7.

25. Viviano $E$, Romano N, Sorce M, Castelli E, Marasà L. Absence of human herpesvirus 8 DNA in benign and malignant endothelial lesions. J Clin Microbiol. 1997;35:3010.

26. Lasota J, Miettinen M Absence of Kaposi's sarcoma-associated virus (human herpesvirus-8) sequences in angiosarcoma. Virchows Arch. 1999;434:51-6.

27. Palacios I, Umbert I, Celada A. Absence of human herpesvirus-8 DNA in angiosarcoma. Br J Dermatol. 1999;140:170-1.

28. Fink-Puches R, Zöchling N, Wolf P, Bäck B, Kerl H, Soyer HP. No detection of human herpesvirus 8 in different types of cutaneous angiosarcoma. Arch Dermatol. 2002;138:131-2

29. Chatlynne LG, Ablashi DV. Seroepidemiology of Kaposi's sarcoma-associated herpesvirus (KSHV). Semin Cancer Biol. 1999;9:175-85.

30. Kamiyama K, Kinjo T, Chinen K, Iwamasa T, Uezato H, Miyagi Jl, et al. Human herpesvirus 8 (HHV8) sequence variations in HHV8 related tumours in Okinawa, a subtropical island in southern Japan. J Clin Pathol. 2004;57:529-35.

\author{
MAILING ADDRESS: \\ João de Magalhães Avancini Ferreira Alves \\ Av. Dr. Enéas de Carvalho Aguiar, 255, $3^{\circ}$ andar \\ Cerqueira César \\ 05403-900 - São Paulo - SP \\ Brazil \\ E-mail: joao.avancini@hc.fm.usp.br
}

How to cite this article: Avancini J, Sanches JA, Cherubim APZ, Pazzini R, Oliveira CM, Sumita LM, Valente NYS, Pannuti CS, Festa Neto C. Angiosarcoma in HIV negative patients is not associated with HHV-8. An Bras Dermatol. 2016;91(6):738-41. 